\author{
๑Л. Б. Маркін, О. І. Попович, А. І. Попович
}

Львівсъкий національний медичний університет імені Данила Галищького

\title{
ДОПЛЕРОМЕТРИЧНЕ ДОСЛІДЖЕННЯ МАТКОВО-ПЛАЦЕНТАРНО-ПЛОДОВОГО КРОВОПЛИНУ У ВАГІТНИХ З ПЕРВИННОЮ АРТЕРІАЛЬНОЮ ГІПОТОНІЕЮ
}

\begin{abstract}
Мета дослідження - вивчення гемодинамічних процесів у системі мати - плацента - плід у вагітних 3 первинною артеріальною гіпотонією.

Матеріали та методи. Проведено доплерометричне дослідження матково-плацентарного та плодово-плацентарного кровоплину у 43 вагітних із первинною артеріальною гіпотонією та 32 здорових вагітних з нормальним артеріальним тиском у терміни гестації - 20-24 тиж., 28-32 тиж., 37-41 тиж. Для оцінки стану гемодинаміки в системі мати - плацента - плід проводилось доплерометричне дослідження кровоплину за допомогою приладу «SA-8000 EX» (Medison, Південна Корея) в акушерських програмах конвексним датчиком (3,5 МГц). Доплерометричне дослідження включало оцінку кровотоку в маткових артеріях, артеріях пуповини та середній мозковій артерії плода.

Результати дослідження та їх обговорення. Виявлено закономірності становлення гемодинамічних процесів у системі мати - плацента - плід у двох групах спостереження. У групі вагітних з первинною артеріальною гіпотонією індекси судинного опору в правій і лівій маткових артеріях були достовірно вищими, ніж у контрольній групі, з переважанням змін у правій матковій артерії. Гемодинамічні прояви при первинній артеріальній гіпотонії з боку матково-плацентарного контуру виглядали при ультразвуковому дослідженні як розширення інтервільозного простору, збільшення поперечного розміру крайового синуса, варикозне розширення параметральних вен. Явища венозного застою у матково-плацентарному контурі супроводжувались вищими показниками індексів судинного опору у маткових артеріях і частіше при динамічному спостереженні призводили до розвитку затримки росту плода. Вивчення гемодинамічних показників в артерії пуповини виявило тенденцію до зростання всіх індексів упродовж вагітності у I групі та зменшення - у II групі; при цьому у вагітних з первинною артеріальною гіпотонією в III триместрі спостерігалось достовірне збільшення показників порівняно з контрольною групою. Вивчення плодової гемодинаміки виявило зниження резистентності кровоплину в середній мозковій артерії плода із прогресуванням вагітності та розвитком централізації кровообігу. Посилення мозкового кровообігу плода є компенсаторною реакцією на хронічну тканинну гіпоксію.

Висновки. Порушення матково-плацентарного кровоплину, які розвиваються у вагітних з первинною артеріальною гіпотонією, починаючи з II триместру вагітності, в подальшому призводять до фетального дистресу.
\end{abstract}

Ключові слова: вагітність; первинна артеріальна гіпотонія; матково-плацентарно-плодова гемодинаміка.

ДОППЛЕРОМЕТРИЧЕСКОЕ ИССЛЕДОВАНИЕ МАТОЧНО-ПЛАЦЕНТАРНО-ПЛОДОВОГО КРОВОТОКА У БЕРЕМЕННЫХ С ПЕРВИЧНОЙ АРТЕРИАЛЬНОЙ ГИПОТОНИЕЙ

Цель исследования - изучение гемодинамических процессов в системе мать - плацента - плод у беременных с первичной артериальной гипотонией.

Материалы и методы. Проведено допплерометрическое исследование маточно-плацентарного и плодово-плацентарного кровотока у 43 беременных с первичной артериальной гипотонией и 32 здоровых беременных с нормальным артериальным давлением в сроки гестации - 20-24 нед., 28-32 нед., 37-41 нед. Для оценки состояния гемодинамики в системе мать - плацента - плод проводилось допплерометрическое исследование кровотока с помощью прибора «SA-8000 EX» (Medison, Южная Корея) в акушерских программах конвексным датчиком (3,5 МГц). Допплерометрическое исследование включало оценку кровотока в маточных артериях, артериях пуповины и средней мозговой артерии плода.

Результаты исследования и их обсуждение. Выявлено закономерности становления гемодинамических процессов в системе мать - плацента - плод в обеих группах наблюдения. В группе беременных с первичной артериальной гипотонией индексы сосудистого сопротивления в правой и левой маточных артериях были достоверно выше, чем в контрольной группе, с преобладанием изменений в правой маточной артерии. Гемодинамические проявления при первичной артериальной гипотонии со стороны маточно-плацентарного контура выглядели при ультразвуковом исследовании как расширение интервиллезного пространства, расширение поперечного размера краевого синуса, варикозное расширение параметральных вен. Явления венозного застоя в маточно-плацентарном контуре сопровождались более высокими показателями индексов сосудистого сопротивления в маточных артериях и чаще при динамическом наблюдении приводили к развитию задержки роста плода. Изучение гемодинамических показателей в артерии пуповины выявило тенденцию к росту всех индексов в течение беременности в I группе и уменьшение - во II группе; при этом у беременных с первичной артериальной гипотонией в III триместре наблюдалось достоверное увеличение показателей по сравнению с контрольной группой. Изучение плодовой гемодинамики выявило снижение резистентности кровотока в средней мозговой артерии плода с прогрессированием беременности и развитием централизации кровообращения. Усиление мозгового кровообращения плода является компенсаторной реакцией на хроническую тканевую гипоксию.

Выводы. Нарушение маточно-плацентарного кровотока, которые развиваются у беременных с первичной артериальной гипотонией, начиная со II триместра беременности, в дальнейшем приводят к фетальному дистрессу.

Ключевые слова: беременность; первичная артериальная гипотония; маточно-плацентарно-плодовая гемодинамика.

DOPPLER EXAMINATION OF UTERINE-PLACENTAL-FETAL HEMODYNAMIC IN PREGNANT WOMEN WITH ARTERIAL HYPOTENSION

The aim of the study - to research the uterine-placental-fetal hemodynamic in pregnant women with arterial hypotension. 
Materials and Methods. Doppler study of blood flow in the uterine-placenta-fetal system is presented in 43 pregnant women with arterial hypotension and 32 pregnant women with normal arterial tension during pregnancy weeks - 20-24, 28-32, 37-41. For the assessment of haemodynamics in the mother-placenta-fetus we used Doppler velocimetry method to study the blood flow using the device «SA-8000 EX» (Medison, South Korea) in obstetric programs with convex transduser (3.5 MHz). Doppler study included the observation and the assessment of blood flow in uterine arteries, artery of the umbilical cord and middle cerebral artery of the fetus.

Results and Discussion. The presence of irregularities in the uterine-placental-fetal system in the both examinated groups was found in the first group indexes of vessel's resistance in the right and level uterine arterias were much more higher than in the second group. The most of changer were presented in the right uterine arteria. Hemodynamic irregularities in pregnant women with arterial hypotension were presented by increasing of the intervillage space, transversal size of regional sine, varicose expansion of parametral veins. The phenomen of venous stagnation were accompanied by the high indexes of vascular resistance in uterine arterias and more often at a dynamic supervision brought a delay of height of fetus. Study of hemodynamic indexer in the artery of umbilical cord revealed the tendency of increase of all indexes during the pregnancy in the first group and their reduction - in the second ( control) group. And it was presented increasing of all indexes in the third trimester of pregnancy in pregnant women with arterial hypotension comparing with the control group. The study of fetal hemodynamics educed the decline of the blood flow resistance in the middle cerebral artery of fetus with progress of pregnancy and centralization of blood circulation. Strengthening of cerebral circulation of the fetus is a compensatory reaction to chronic tissue hypoxia.

Conclusions. Irregularities of the utero-placental blood flow that is developing in pregnant women with primary arterial hypotension, starting from the second trimester of pregnancy lead to fetal distress.

Key words: pregnancy; hypotension; uterine-placental-fetal hemodynamic.

ВСТУП. Первинна артеріальна гіпотонія (ПАГ) - самостійна мультифакторіальна патологія нейроендокринної природи, головною гемодинамічною ланкою патогенезу якої є первинне порушення тонусу судин і їх реактивності, що зумовлено дією спадкових та довкільних фракторів і проявляється поряд із пониженням АТ суб'єктивною та об'єктивною симптоматикою. Виділяють фрізіологічну ПАГ, при якій відсутні як суб'єктивні, так і об'єктивні розлади без змін працездатності, що, на думку авторів, повинно було б протиставлятися, так званій, «патологічній». У свою чергу, деякі вчені такий поділ вважають умовним і недоцільним, оскільки фрізіологічна ПАГ є преморбідним станом, який у часі виснаження адаптаційних резервів гемодинаміки переходить у гіпотонічну хворобу, або ПАГ, для якої присутні більш-менш окреслені власні клінічні прояви [5].

Яскравим прикладом $€$ перебіг вагітності та пологів у жінок з ПАГ. Фізіологічне зростання ємкості судинного русла, виникнення додаткової матково-плацентарної системи кровообігу, секреція плацентою гормонів, які пригнічують функцію гіпофріза, в результаті чого зменшується продукція пресорних речовин; імунна реакція на антигени плаценти і плода, в результаті чого змінюється виділення ряду біологічно активних речовин, зокрема катехоламінів, ацетилхоліну, серотоніну, гістаміну, приводять до виснаження процесів адаптації та компенсації жінок з АГ та виникнення значної кількості ускладнень перебігу вагітності та пологів.

Судинний опір з початком фрізіологічної вагітності знижується на 30-40 \%. Для ПАГ характерним є вихідне патологічне зниження перифреричного судинного тонусу, зниження судинорухової функції, що може стати причиною погіршеного кровопостачання і, як наслідок, тривалої ішемії матки. Крім того, переважання тонусу парасимпатичної нервової системи призводить до розширення кровоносних судин матки та венозного застою. Таким чином, порушення вегетативної регуляції судинного тонусу з переважанням ваготонічних реакцій крові при ПАГ супроводжується зниженням перфузії органів і тканин, що зумовлює порушення припливу крові в міжворсинкове русло, та утрудненням відтоку венозної крові від нього і, як наслідок, розвитком плацентарної диссрункції (ПД) [4].
У даний час єдиним реальним шляхом зниження розвитку ПД є рання діагностика та профрілактика цього ускладнення вагітності. Одним із основних методів діагностики ПД є ультразвукова доплерометрія, за допомогою якої визначають параметри кровоплину в маткових артеріях (МА), артеріях пуповини (АП) та середній мозковій артерії (СМА) плода. Питанням вивчення гемодинаміки в системі мати - плацента - плід при фрізіологічному та патологічному перебігу вагітності присвячена велика кількість робіт $[1,2,8]$. Проте, незважаючи на наявність наукових досліджень у даному напрямку, матково-плацентарний кровоплин (МПК) та плодово-плацентарний кровоплин (ППК) у вагітних з ПАГ потребують подальшого вивчення.

МЕТА ДОСЛІДЖЕННЯ - вивчення гемодинамічних процесів у системі мати - плацента - плід у вагітних з ПАГ.

МАТЕРІАЛИ ТА МЕТОДИ. Проведена ультразвукова фретометрія внутрішньоутробного плода та доплерометричне дослідження кровоплину в системі мати - плацента - плід у II і III триместрах вагітності на фоноі ПАГ. Дослідження проводились у 43 пацієнток з ПАГ (I група) у терміні гестації від 20 до 41 тиж. $з$ характерними для даного стану скаргами різного ступеня вираженості (загальна слабість, швидка втома, головний біль, періодичні головокружіння, метеозалежність) та 32 здорових вагітних з нормальним артеріальним тиском, які увійшли до контрольної групи (II група). Середній вік вагітних у групах склав $(29,4 \pm 1,6)$ року і $(27,8 \pm 2,1)$ року відповідно. У I групі жінки, які народжуватимуть вперше, склали 32 (74,4 \%), серед них з першою вагітністю - 23 (53,5 \%); у II групі - 20 (62,5 \%) і 14 (43,8 \%) відповідно.

Дослідження проводилось тричі - в терміні вагітності 20-24 тиж., 28-32 тиж., 37-41 тиж. 3 урахуванням комплексної оцінки гемодинаміки А. Н. Стрижаковым, А. Г. Григоряном (1990) [9] була розроблена класифрікація порушень МПК та ППК, згідно з якою до ІА ступеня порушень відносили випадки з нормальним ППК, але порушеним МПК; до ІБ ступеня - випадки з нормальним МПК та зниженим ППК; до II ступеня - випадки з порушеним як МПК, так і ППК, але із збереженим діастолічним кровоплином в АП; до III, критичного, ступеня - випадки з відсутністю кровоплину в АП при збереженому або зниженому МПК. 
Усі вагітні були проінформовані про мету дослідження і дали згоду на участь у ньому.

Для оцінки стану гемодинаміки в системі мати - плацента - плід проводилось доплерометричне дослідження кровоплину за допомогою приладу «SA-8000 EX» (Medison, Південна Корея) в акушерських програмах конвексним датчиком (3,5 МГц). Доплерометричне дослідження включало оцінку кровотоку в МА, АП та СМА плода. Оцінювали співвідношення між максимальною систолічною швидкістю кровоплину, яка відображає скоротливу фрункцію серця й еластичність стінок судини, та кінцевою діастолічною швидкістю кровоплину, яка залежить від ступеня опору перифреричного судинного русла. Для якісного аналізу стану кровоплину обчислювали систоло-діастолічне відношення (С/Д); індекс резистентності (IP); пульсаційний індекс (ПІ) При аналізі результатів доплерометрії враховували рекомендації Л. Б. Маркіна, К. Л. Шатилович [6].

Статистичне оброблення результатів дослідження проводили на персональному комп'ютері 3 використанням сучасних методів варіаційної статистики [8] за допомогою стандартних програм статистичного аналізу Microsoft Excel 7.0, Statistica 6.0.

РЕЗУЛЬТАТИ ДОСЛІДЖЕННЯ ТА ЇХ ОБГОВОРЕНня. Проведені доплерометричні дослідження показників кровоплину в системі мати - плацента - плід дозволили виявити закономірності становлення МПК та ППК у двох групах спостереження. Так, у контрольній групі середні значення індексів судинного опору (ICO) в МА мали тенденцію до поступового зниження до завершення вагітності. Отримані результати можна пояснити зростанням діасто- лічної швидкості кровоплину в МА у II половині вагітності, що збігається з даними дослідження інших авторів $[1,10]$. У групі вагітних з ПАГ ІСО в правій і лівій МА були достовірно вищими, з переважанням змін у правій МА, яка, як відомо, має перевагу у кровопостачанні матки. При цьому порушення МПК відмічались з 20-24 тиж. і зниження ICO до кінця вагітності не спостерігалось (табл. 1).

Гемодинамічні прояви при ПАГ з боку матково-плацентарного контуру гемодинаміки полягали у розширенні інтервільозного простору, розширенні крайового синуса та параметральних вен. Ехографрічне зображення крайового синуса виглядало як гіпоехогенна щілиноподібна структура, розташована між зовнішнім краєм плаценти, гладким хоріоном та децидуальною оболонкою. При неускладненій вагітності найбільший поперечний розмір крайового синуса не перевищував 7 мм. У жінок з ПАГ поперечний розмір крайового синуса плаценти складав $(9,3 \pm 1,2)$ мм у II триместрі; при доношеній вагітності - $(16,9 \pm 2,1)$ мм.

Явища венозного застою (рис. 1) у матково-плацентарному контурі супроводжувались вищими показниками ICO у MA і частіше при динамічному спостереженні призводили до розвитку затримки росту плода (ЗРП).

Про більш глибокі порушення матково-плацентарної гемодинаміки свідчила поява дикротичної виїмки у фразу ранньої діастоли (рис. 2). У наших дослідженнях рання діастолічна виїмка в кривих швидкостей кровоплину в МА виявлена лише у 2-х вагітних I групи: у першої - в 23-24 тиж. гестації в поєднанні із високими ICO в МА (вагітність завершилась достроковим розродженням у 32-33 тиж.); у другої - за гестацією 32 тиж., за даними фретометрії -

Таблиця 1. Індекси судинного опору в маткових артеріях

\begin{tabular}{|c|c|c|c|c|c|c|c|}
\hline \multirow{2}{*}{$\begin{array}{c}\text { Термін } \\
\text { вагітності, } \\
\text { тиж. }\end{array}$} & \multirow{2}{*}{$\begin{array}{l}\text { Маткові } \\
\text { артерії }\end{array}$} & \multicolumn{2}{|c|}{ С/Д } & \multicolumn{2}{|c|}{ IP } & \multicolumn{2}{|c|}{ П। } \\
\hline & & група 1 & група 2 & група 1 & група 2 & група 1 & група 2 \\
\hline \multirow[t]{2}{*}{$20-24$} & права & $2,06^{*} \pm 0,02$ & $1,99 \pm 0,02$ & $0,54 \pm 0,03$ & $0,52 \pm 0,03$ & $0,86^{\star} \pm 0,02$ & $0,78 \pm 0,02$ \\
\hline & ліва & $1,92^{\star} \pm 0,01$ & $1,87 \pm 0,02$ & $0,50 \pm 0,03$ & $0,48 \pm 0,02$ & $0,82^{\star} \pm 0,02$ & $0,74 \pm 0,03$ \\
\hline \multirow[t]{2}{*}{$28-32$} & права & $2,09^{\star} \pm 0,02$ & $1,93 \pm 0,03$ & $0,52^{\star} \pm 0,03$ & $0,42 \pm 0,03$ & $0,88^{*} \pm 0,04$ & $0,69 \pm 0,04$ \\
\hline & ліва & $1,96^{\star} \pm 0,02$ & $1,90 \pm 0,02$ & $0,48^{\star} \pm 0,02$ & $0,40 \pm 0,04$ & $0,80 * \pm 0,05$ & $0,64 \pm 0,03$ \\
\hline \multirow[t]{2}{*}{$37-41$} & права & $2,14^{\star} \pm 0,05$ & $1,88 \pm 0,05$ & $0,58^{\star} \pm 0,04$ & $0,38 \pm 0,03$ & $0,94^{\star} \pm 0,05$ & $0,60 \pm 0,03$ \\
\hline & ліва & $1,95^{\star} \pm 0,06$ & $1,82 \pm 0,04$ & $0,50^{\star} \pm 0,05$ & $0,33 \pm 0,04$ & $0,79^{\star} \pm 0,04$ & $0,57 \pm 0,02$ \\
\hline
\end{tabular}

Примітка. * - відмінності вірогідні $(p<0,05)$ порівняно з контрольною групою (II).

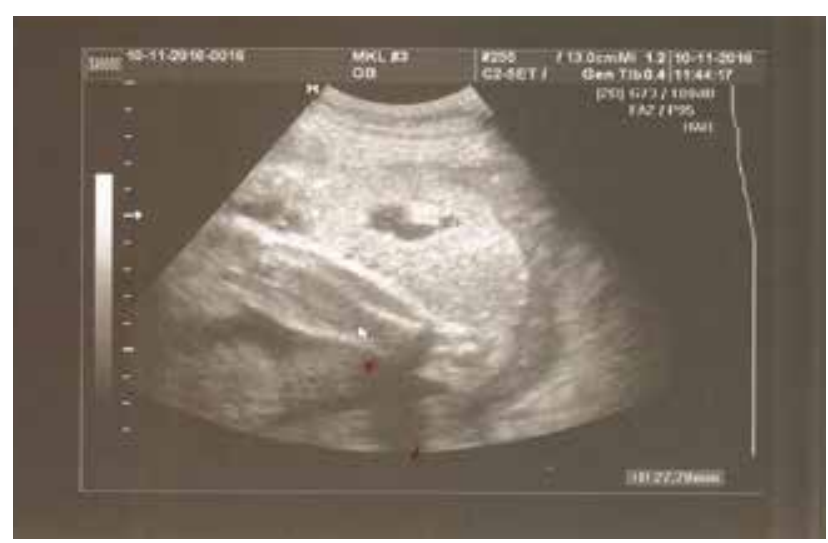

Рис. 1. Вагітність 32-33 тиж. Розширення інтервільозного простору діаметром 27,70 мм.

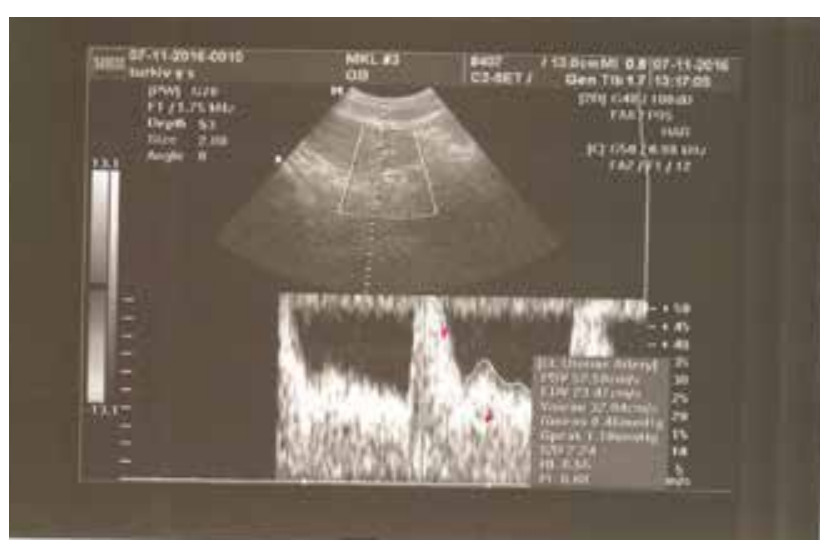

Рис. 2. Вагітність 32-33 тиж. Доплерограма КшК у матковій артерії. Дикротична виїмка. 
28-29 тиж. (вагітність завершилась пологами у 37-38 тиж. вагою 2200,0, довжиною 48 см).

Таким чином, доплерометрія в МА в поєднанні з ультразвуковими змінами плаценти, починаючи з II триместру, дозволила нам виділити групу ризику із виникнення ЗРП та ПД. Первинною ланкою виникнення гемодинамічних порушень у вагітних з ПАГ стали порушення МПК, тобто порушення кровоплину I А ступеня.

Доплерометричну оцінку ППК проводили за станом кровоплину в АП, оскільки єдиним периферійним руслом для них є мікроваскулярна сітка плодової частини плаценти. В АП упродовж неускладненої вагітності спостерігалось достовірне зниження судинного опору [10]. В цьому основну роль відіграють анатомічні зміни васкуляризації ворсин, які характеризуються прогресуючим збільшенням числа ворсин і підвищенням частки судин на одиницю площі поперечного розрізу кожної ворсини (процеси «фреталізації» плаценти). Порушення припливу крові до матки у жінок з ПАГ, яке проявляється порушенням МПК, починаючи з II триместру, приводить в подальшому до зменшення васкуляризації термінальних ворсин у плаценті, веде за собою підвищення периферійного судинного опору і зниження діастолічного кровоплину (збільшення
ICO) в АП. Вивчення гемодинамічних показників в АП виявило тенденцію до зростання всіх індексів в I групі та до зменшення - у II групі; при цьому у вагітних з ПАГ в III триместрі спостерігалось достовірне $(p<0,05)$ збільшення показників порівняно з контрольною групою (табл. 2).

Прогресування розладів матково-плацентарно-плодової гемодинаміки можуть призводити до зниження кровоплину, зменшення перфузійних процесів, i, в кінцевому результаті, до погіршення обмінних процесів в організмі плода, що клінічно може проявлятися ЗРП.

В оцінці функціонального стану плода велике значення має вивчення плодової гемодинаміки. За даними сучасних авторів, доплерометрія швидкостей кровоплину СМА плода $є$ найбільш інформативною [3]. При вивченні кровоплину в СМА плода у вагітних з ПАГ виявили зниження резистентності із прогресуванням вагітності, що проявлялося підвищенням діастолічного компонента i, як наслідок, зниженням ICO (табл. 3).

Посилення мозкового кровоплину на фоні змінених показників ППК виникають у жінок з ПАГ не за рахунок порушення формування плаценти, а мають екстраплацентарне походження, і $є$ компенсаторною реакцією на хронічну тканинну гіпоксію.

Таблиця 2. Індекси судинного опору в артеріях пуповини

\begin{tabular}{|c|c|c|c|c|c|c|}
\hline \multirow{2}{*}{$\begin{array}{c}\text { Термін } \\
\text { вагітності, } \\
\text { тиж. }\end{array}$} & \multicolumn{2}{|c|}{ С/Д } & \multicolumn{2}{|c|}{ IP } & \multicolumn{2}{|c|}{ חI } \\
\hline & група 1 & група 2 & група 1 & група 2 & група 1 & група 2 \\
\hline $20-24$ & $3,53 \pm 0,06$ & $3,42 \pm 0,06$ & $0,72 \pm 0,02$ & $0,71 \pm 0,04$ & $1,21 \pm 0,05$ & $1,12 \pm 0,06$ \\
\hline \multirow[t]{2}{*}{$28-32$} & $2,81^{*} \pm 0,04$ & $2,57 \pm 0,05$ & $0,63 \pm 0,04$ & $0,59 \pm 0,03$ & $0,99 \pm 0,06$ & $0,89 \pm 0,05$ \\
\hline & $3,02^{*} \pm 0,03$ & $2,82 \pm 0,04$ & $0,72 \pm 0,05$ & $0,65 \pm 0,04$ & $1,02 \pm 0,04$ & $0,98 \pm 0,03$ \\
\hline \multirow[t]{2}{*}{$37-41$} & $3,15^{\star} \pm 0,05$ & $2,25 \pm 0,03$ & $0,74^{\star} \pm 0,05$ & $0,49 \pm 0,03$ & $0,91^{*} \pm 0,05$ & $0,70 \pm 0,04$ \\
\hline & $3,22^{*} \pm 0,04$ & $2,32 \pm 0,04$ & $0,78^{\star} \pm 0,04$ & $0,58 \pm 0,05$ & $1,12^{\star} \pm 0,06$ & $0,78 \pm 0,05$ \\
\hline
\end{tabular}

Примітка. * - відмінності вірогідні $(p<0,05)$ порівняно з контрольною групою (II).

Таблиця 3. Індекси судинного опору в середній мозковій артерії плода

\begin{tabular}{|c|c|c|c|c|c|c|}
\hline \multirow{2}{*}{$\begin{array}{c}\text { Термін } \\
\text { вагітності, тиж. }\end{array}$} & \multicolumn{2}{|c|}{ С/Д } & \multicolumn{2}{|c|}{ IP } & \multicolumn{2}{|c|}{ ПI } \\
\hline & група 1 & група 2 & група 1 & група 2 & група 1 & група 2 \\
\hline $20-24$ & $5,25 \pm 0,27$ & $5,70 \pm 0,23$ & $0,76 \pm 0,04$ & $0,81 \pm 0,07$ & $1,66 \pm 0,05$ & $1,72 \pm 0,09$ \\
\hline $28-32$ & $4,66^{\star} \pm 0,23$ & $5,25 \pm 0,17$ & $0,72 \pm 0,04$ & $0,79 \pm 0,06$ & $1,41 \pm 0,03$ & $1,47 \pm 0,05$ \\
\hline $37-41$ & $3,32^{*} \pm 0,12$ & $3,76 \pm 0,11$ & $0,67^{\star} \pm 0,02$ & $0,74 \pm 0,03$ & $0,82^{\star} \pm 0,02$ & $0,93 \pm 0,05$ \\
\hline
\end{tabular}

Примітка. * - відмінності вірогідні $(p<0,05)$ порівняно з контрольною групою (II).

ВИСНОВКИ. 1. Вагітних з ПАГ слід відносити до групи ризику з виникнення ПД.

2. Починаючи з II триместру вагітності, у них розвиваються порушення МПК, які належать до порушень ІА ступеня.

3. Порушення кровопостачання матки та погіршений венозний відтік упродовж тривалого часу призводить до змін у плацентарно-плодовому басейні, і проявляється централізацією гемодинаміки плода.

ПЕРСПЕКТИВИ ПОДАЛЬШИХ ДОСЛІДЖЕНЬ. ДЛЯ попередження виникнення перинатальних ускладнень у вагітних з ПАГ, починаючи 3 II триместру вагітності, вивчити застосування венотоніків системної дії.

\section{СПИСОК ЛІТЕРАТУРИ}

1. Апресова К. Г. Особенности маточно-плацентарного кровообращения при артериальной гипотонии у беременных / К. Г. Апресова, Е. Н. Дзюба // Перинатология и педиатрия. -2006 . - № 3 (27). - C. 81-82.
2. Вдовиченко Ю. П. Особливості матково-плацентарної та плодово-плацентарної гемодинаміки при різних формах плацентарної диссункції / Ю. П. Вдовиченко, А. П. Садовий // Педіатрія, акушерство та гінекологія. -2011. - № 2. - С. 73-77. 
3. Волик К. Н. Методологические аспекты допплерометрической оценки маточно-плацентарной гемодинамики / К. Н. Волик // Лучевая диагностика, лучевая терапия. -2012. - № 4. - С. 77-83.

4. Воробей Л. І. Порушення нейровегетативної регуляції і вагітність: вплив на розвиток гестаційних ускладнень / Л. І. Воробей // Здоровье женщины. - 2015. - № 6 (102). C. $97-98$.

5. Жовнір І. І. Нестабільність артеріального тиску при первинній артеріальній гіпотонії / І. І. Жовнір // Військова медицина України. - 2011. - Т. 11, № 3-4. - С. 58-62.

6. Маркін Л. Б. Доплерометрія в акушерстві: гемодинамічні особливості функціональної системи мати - плацента - плід / Л. Б. Маркін, К. Л. Шатилович // Репродуктивное здоровье женщины. - 2007. - № 1 (30). - С. 26-39.

\section{REFERENCES}

1. Apresova, K.G., \& Dzyuba, E.N. (2006). Osobennosti matochno-platsentarnogo krovoobrashcheniya pri arterialnoi hipotonii u beremennykh [Features of utero-placental blood flow during hypotension in pregnant]. Perinatologiya $i$ pediatriya Perinatology and Pediatrics, 3 (27), $81-82$ [in Russian].

2. Vdovichenko, Yu.P., \& Sadovyi, A.P. (2011). Osoblyvosti matkovo-platsentarnoi hemodynamiky pry riznykh formakh platsentarnoi dysfunktsii [Features of utero-placental and fetal-placental hemodynamics in various forms of placental dysfunction]. Pediatriya, akucherstvo ta hinekolohiya Pediatrics, Obstetrics and Gynecology, 2, 73-77 [in Ukrainian].

3. Volik, K.N. (2012). Metodologicheskiye aspekty dopplerometricheskoi otsenki matochno-platsentarnoi hemodinamik [Methodological aspects of Doppler assessment of utero-placental hemodynamics]. Luchevaya diagnostika, luchevaya terapiya - X-ray diagnostics, $X$-ray therapy, 4, 77-83 [in Ukrainian].

4. Vorobei, L.I. (2015). Porushennia neirovehetatyvnoi rehulatsii i vahitnist: vplyv na rozvytok hestatsiinykh uskladnen [Irregularities of neurovegetative regulation and pregnancy: impact on the development of gestational complications]. Zdorovye zhenshchiny - Women's Health, 6 (102), 97-98 [in Ukrainian].

5. Zhovnir, I.I. (2011). Nestabilnist arterialnogo tysku pry pervynnii arterialnii hipotonii [Unstable blood pressure in primary arterial hypotension]. Viiskova medytsyna Ukrainy - Military Medicine of Ukraine, 11, 3-4; 58-62 [in Ukrainian].

6. Markin, L.B., \& Shatylovych, K.L. (2007). Doplerometriya v akusherstvi: hemodynamichni osoblyvosti funktsionalnoi systemy
7. Мінцер О. П. Оброблення клінічних і експериментальних даних у медицині / О.П.Мінцер, Ю.В.Вороненко, В. В. Власов. - К. : Вища школа, 2003. - 350 с.

8. Современный подход к профилактике и лечению фретоплацентарной недостаточности при артериальной гипотензии у беременных / З. К. Рахимова, Д. Ф. Каримова, Э. Ш. Алиев, С. А. Мирходжаева // Репродуктивное здоровье женщины. - 2007. - № 4 (33). - С. 39-41.

9. Стрижаков А. Н. Анатомо-фрункциональные особенности гемодинамики в системе мать - плацента - плод / А. Н. Стрижаков, Г. А. Григорян // Акушерство и гинекология. - 1990. - № 5. - С. 11-13.

10. Стрижаков А. Н. Современные методы оценки состояния матери и плода при беременности высокого риска/ А. Н. Стрижаков, И. В. Игнатко // Вопросы гинекологии, акушерства и перинатологии. - 2009. - № 2 (8). - С. 5-15.

maty-platsenta-plid [Doppler in obstetrics: hemodynamic features of functional system mother-placenta-fetus]. Reproduktivnoye zdorovye zhenshchiny - Reproductive Health of Women, 1 (30), 26-39 [in Ukrainian].

7. Mintser, O.P., Voronenko, Y.V., \& Vlasov, V.V. (2003). Obroblennya klinichnykh i eksperymentalnykh danykh u medytsyni [Treatment of clinical and experimental data in medicine]. Kyiv: High School [in Ukrainian].

8. Rakhimova, Z.K., Karimova, D.F., Aliyev, E.Sh., \& Mirkhodzhayeva, S.A. (2007). Sovremennii podkhod k profilaktike i lecheniyu fetoplatsentarnoi nedostatochnosti pri arterialnoi hipotezii beremennykh [The modern approach to the prevention and treatment of placental insufficiency in patients with arterial hypotension in pregnant]. Reproduktivnoye zdorovye zhenshchiny - Reproductive Health of Women, 4 (33), 39-41[in Ukrainian].

9. Strizhakov, A.I. , \& Grigoryan, G.A. (1990). Anatomofunktsionalnyye osobennosti hemodinamiky $v$ sisteme mat-platsenta-plod [Anatomical and functional features of gemodynamics in the system mother-placenta-fetus] Akucherstvo i ginekologiya - Obstetrics and Gynecology, 5, 11-13 [in Russian].

10. Strizhakov, A.I. , \& Ignatko, I.V. (2009). Sovremennyye metody otsenki sostoyaniya materi i ploda pri beremennosti vysokogo riska [Modern methods of assessing the state of the mother and fetus during high-risk pregnancy]. Voprosy ginekologii, akucherstva i perinatologii - Questions of Gynecology, Obstetrics and Perinatology, 2 (8), 5-15 [in Ukrainian]. 